https://helda.helsinki.fi

\title{
Wild plant gathering in Stone Age Finland
}

\section{Vanhanen, Santeri}

2016

Vanhanen, S \& Pesonen, P 2016 , ' Wild plant gathering in Stone Age Finland ',

Quaternary International, vol. 404, Part A , pp. 43-55 . https://doi.org/10.1016/j.quaint.2015.10.036

http://hdl.handle.net/10138/176907

https://doi.org/10.1016/j.quaint.2015.10.036

submittedVersion

Downloaded from Helda, University of Helsinki institutional repository.

This is an electronic reprint of the original article.

This reprint may differ from the original in pagination and typographic detail.

Please cite the original version. 


\title{
Wild plant gathering in Stone Age Finland
}

\author{
Santeri Vanhanen ${ }^{\text {a, }}$, Petro Pesonen ${ }^{\mathrm{a}, \mathrm{b}}$ \\ a Department of Philosophy, History, Culture and Art Studies, Archaeology, University of Helsinki, P.O. Box 59, FI-00014, Helsinki, Finland \\ ${ }^{\mathrm{b}}$ Archaeological Field Services, National Board of Antiquities, P.O. Box 913, FI-00101, Helsinki, Finland
}

\section{A R T I C L E I N F O}

\section{Article history:}

Available online xxx

\section{Keywords:}

Archaeobotany

Wild plant gathering

Subsistence

Finland

Neolithic

Mesolithic

\begin{abstract}
A B S T R A C T
In this paper, a systematic review of archaeobotanical data from Stone Age (c. 8900-1500 cal BC) sites in mainland Finland is presented for the first time and compared with ethnographical data. The data was collected from 76 archaeological sites and consists of charred and waterlogged remains from soil samples and charred hand-picked remains from archaeological excavations. The data shows that various wild plants were gathered in Finland during the Stone Age and that different opportunities for plant gathering prevailed in various parts of the country. Hazel and water chestnut were widespread and used in locales further to the north than where they grow today, but they were still confined to southern Finland. Some plants, such as bearberry and crowberry, were ubiquitous and collected throughout Finland. In the light of the data analysed, it is suggested that most of the charred plant remains derive from food processing (roasting, smoking, frying, cooking), waste management, and fuel use.
\end{abstract}

(C) 2015 Elsevier Ltd and INQUA. All rights reserved.

\section{Introduction}

Stone Age societies in Finland based their subsistence mainly on hunting and gathering. Small-scale cultivation was practiced sporadically. Stone Age plant gathering has received much less attention than hunting (e.g. Edgren, 1993), even though the importance of gathering has been understood and the need for more archaeobotanical analyses has been acknowledged (Zvelebil, 1994). Studies of Stone Age subsistence and cultural ecology have previously been based on zooarchaeological and artefactual evidence, while aspects of foraging subsistence practices related to plant gathering have received much less attention (e.g. Siiriäinen, 1981; Nunez, 1990). When the availability of wild plants (Nunez, 1990) and plant cultivation (Siiriäinen, 1982; Nunez, 1999) have been discussed elsewhere, archaeobotanical data has played a minor role. One exception, however, is Hertell (2009), who has used hand-picked hazelnut shells from excavations as a proxy for the portion of vegetable foods in the hunter-gatherer diet.

This apparent downplay of archaeobotanical material is most probably due to the fact that no earlier synthesis has been made of Stone Age archaeobotanical material for the whole of mainland Finland, even though a small number of papers have been published (e.g. Jussila, 1996; Lempiäinen, 2010). The main challenge

\footnotetext{
* Corresponding author.

E-mail address: santeri.vanhanen@gmail.com (S. Vanhanen).
}

regarding this data category is that most archaeobotanical research results are generally only available in 'grey' literature, such as plant lists or separate reports attached to main excavation reports. Therefore, our first objective is to compile and review the available archaeobotanical data on plant remains from Stone Age mainland Finland and to map the use of wild plants in different parts of the country.

It can be difficult to interpret the archaeobotanical remains of wild plants. Ethnographical and historical accounts provide information on how the plants could have been used and consumed. Our second objective is to discuss how the plants found in Stone Age Finland could have been used. This discussion is based on a survey of Finnish ethnographical and historical literature, relevant archaeobotanical literature, and old floras. Our main focus is on the preparation and consumption of plants as food, even though we acknowledge that plants have been used for various other purposes.

Finland is located in the circumpolar region, approximately between the 60th and 70th parallels north, which limits the distribution and growth of plants (Fig. 1a, b). There are significant differences in climate and vegetation from one extreme to the other and gradual changes between them. However, climate and vegetation have changed during the millennia. The climate was warmer during the Holocene thermal maximum, which allowed thermophilous plants to grow further north. Our third objective in this paper is to compare the distribution of the most common plant taxa from Stone Age sites with the current distribution of these plants. 


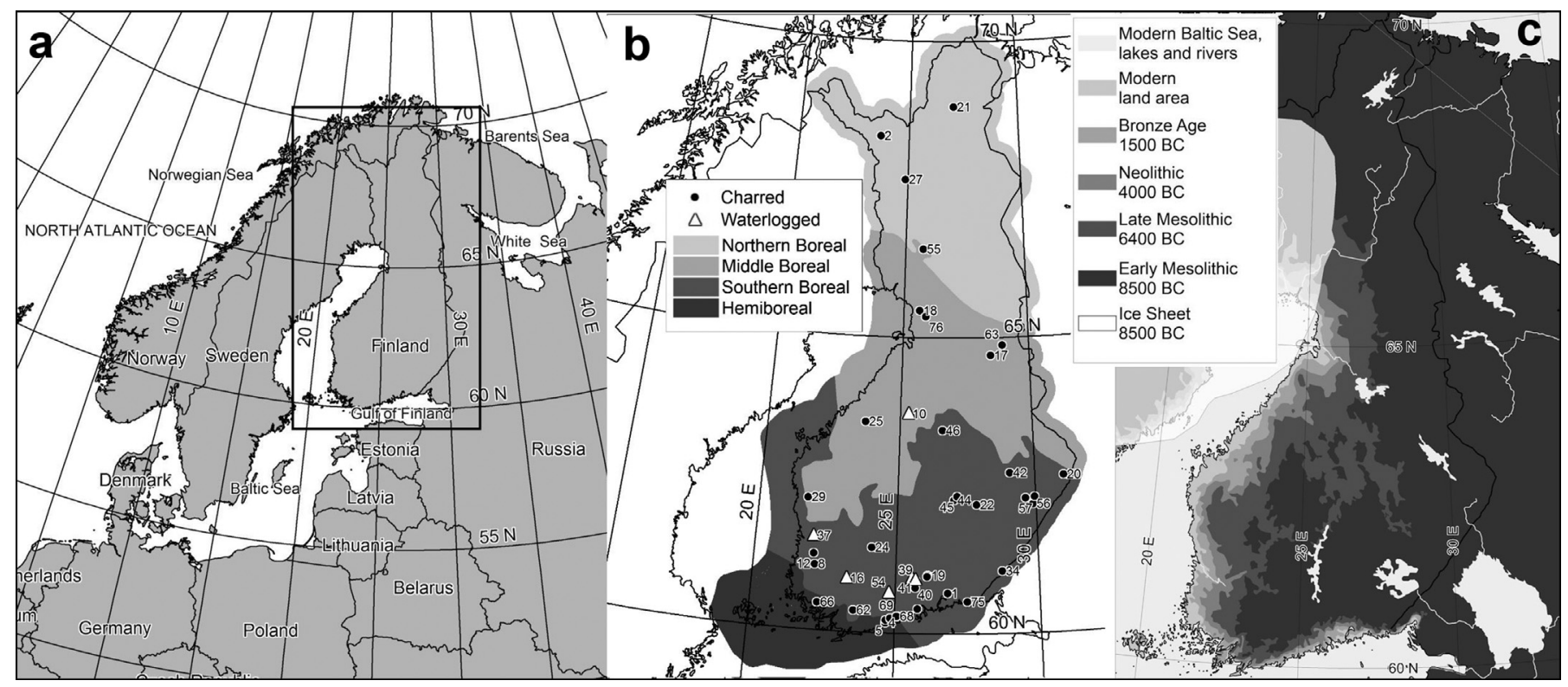

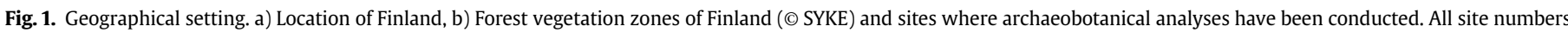

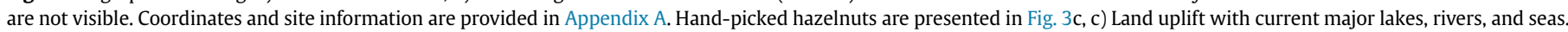

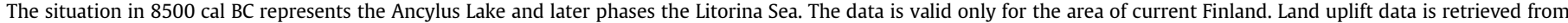
Daniels 2010 unpublished digital atlas; Påsse and Daniels, 2011.

This comparison can illustrate how the Holocene thermal maximum changed the distribution of these plant species.

\subsection{Regional and chronological setting}

The geographical area covered by this study is mainland Finland (Fig. 1), excluding the Åland archipelago in the south-western part of Finland. The chronological limit is the Finnish Stone Age (c. 8900-1500 cal BC), based on Carpelan's (1999, 2002) chronology.

Most of Finland consists of lowlands below $200 \mathrm{~m}$ a.s.l., but there is a lot of local variation in the topography. Areas with higher elevation are mainly situated in eastern and northern Finland, which also emerged first after the last glaciation (Fig. 1c; Tikkanen, 1994). During the Holocene, land uplift changed Finland's land area drastically. Fig. 1c summarizes this development, where the first phase of 8500 cal BC represents Ancylus Lake (c. 8700-6200 cal BC). A marked change took place in the Baltic Sea c. $6200 \mathrm{cal}$ BC, when the former Ancylus Lake transformed into the salty Litorina Sea (Andrén et al., 2000).

Varied environmental conditions between both north-south and east-west axes provided habitats for different animals and plants. This variation can also be seen in the archaeological record. Maritime hunting and fishing were preferred in the coastal regions, whereas terrestrial hunting and fishing in lakes and rivers were common forms of subsistence in the inland regions. Freshwater plants were readily available due to the large number of freshwater basins, especially in south-eastern and central Finland (Fig. 1c).

\subsection{Current vegetation}

Finland lies mostly in the boreal zone, which is further divided according to the spread of tree taxa and vegetation into the southern, middle, and northern sub-zones (Fig. 1b). Only the south-western parts of the country are situated in the transitional hemiboreal zone. The Finnish boreal zone is characterized by coniferous forests, where Scots pine (Pinus sylvestris) and Norway spruce (Picea abies) are the main woody species (Hotanen et al., 2013).

In Finland, coniferous forests are common in the hemiboreal zone, which is defined by the occurrence of English oak (Quercus robur) (Valste et al., 2006). It is a transitional zone between the southern nemoral and northern boreal zones, characterized by a limited inclusion of thermophilous deciduous trees, and it has the richest vegetation and the greatest amount of groves in Finland, especially in places with alkaline bedrock (Kuusipalo, 1996; Valste et al., 2006).

The northern limit of the southern boreal zone is defined by the distribution of small-leaved lime (Tilia cordata) (Valste et al., 2006). Thermophilous trees are less common than in the hemiboreal zone, but small-leaved lime (Tilia cordata), hazel (Corylus avellana) and wych elm (Ulmus glabra) grow occasionally in groves (Valste et al., 2006). The predominant tree species in the zone are Scots pine (Pinus sylvestris) and Norway spruce (Picea abies), and spruce forests are rather common (Kuusipalo, 1996).

Due to climatic factors, spruce and pine produce less biomass in the middle boreal zone (Valste et al., 2006). Its northern limit is more or less defined by the distribution of alder (Alnus glutinosa), and thermophilous trees are rare in this zone (Valste et al., 2006).

The northern boreal zone is characterized by the slow growth of trees and sparse forests. The only tree species growing in this zone are spruce, pine, and birch (Valste et al., 2006). Treeless areas prevail in the northernmost parts of this zone.

\subsection{Archaeological background and development of subsistence strategies}

Table 1 presents the periodization of the study and the main subsistence strategies during these periods. Typologies and their dating follow those defined by Carpelan (1999, 2002), with the exception that the beginning of the Late Neolithic is set as $c$. 3400 cal BC instead of Carpelan's c. 2300 cal BC. Chronological limits are tentative and their aim here is merely to contextualize the archaeobotanical data. 
Table 1

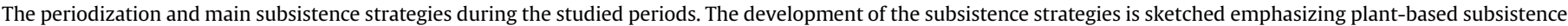
and plant cultivation. Variations in subsistence in the different parts of the country are acknowledged, but not discussed here.

\begin{tabular}{|c|c|c|c|}
\hline Period & Dating & Subsistence (plant-based subsistence emphasized) & Ceramic types \\
\hline Early Mesolithic (Ancylus Lake) & $8900-6500$ cal BC & Foraging (Matiskainen, 1989; Nunez, 1999) & No ceramics \\
\hline $\begin{array}{l}\text { Late Mesolithic (Ancylus Lake/ } \\
\quad \text { Litorina Sea) }\end{array}$ & $6500-5200 \mathrm{cal} \mathrm{BC}$ & Foraging (Matiskainen, 1989; Nunez, 1999) & No ceramics \\
\hline Early Neolithic (Litorina Sea) & $5200-4000$ cal BC & $\begin{array}{l}\text { Foraging (Nunez, 1999) and first occurrence of } \\
\text { Hordeum-type and buckwheat (Fagopyrum } \\
\text { esculentum) pollen (Alenius et al., 2013) }\end{array}$ & $\begin{array}{l}\text { Early Comb Ware (Ka 1:1 and Ka 1:2), Säräisniemi } 1 \\
\text { Ware, Jäkärlä Ware, Early Asbestos Ware }\end{array}$ \\
\hline Middle Neolithic (Litorina Sea) & $4000-3400 \mathrm{cal} \mathrm{BC}$ & $\begin{array}{l}\text { Foraging (Nunez, 1999) and small-scale cultivation } \\
\text { suggested by pollen occurrences (Mökkönen, 2010) }\end{array}$ & $\begin{array}{l}\text { Typical Comb Ware (Ka 2), Late Comb Ware (Ka 3), } \\
\text { Kierikki Ware }\end{array}$ \\
\hline Late Neolithic (Litorina Sea) & $3400-1800 \mathrm{cal} \mathrm{BC}$ & $\begin{array}{l}\text { Foraging (Nunez, 1999), increase in cerealia-type } \\
\text { pollen (Vuorela, 1999), and first barley grains } \\
\text { possibly dated to the very end of the period } \\
\text { (Vuorela and Lempiäinen, 1988). Cultivation seems } \\
\text { to have been small-scale before the introduction of } \\
\text { the Corded Ware culture (Mökkönen, 2010) }\end{array}$ & $\begin{array}{l}\text { Pyheensilta Ware, Pöljä Ware, Jysmä Ware, Corded } \\
\text { Ware, Kiukainen Ware }\end{array}$ \\
\hline Bronze Age (Litorina Sea) & $1800-500 \mathrm{cal} \mathrm{BC}$ & $\begin{array}{l}\text { AMS-dated cereal grains show that barley was the } \\
\text { main crop (Vanhanen and Koivisto, 2015). Cerealia } \\
\text { pollen occurring more often (Vuorela, 1999) }\end{array}$ & $\begin{array}{l}\text { Paimio Ware, Sarsa-Tomitsa Ware, Lovozero Ware, } \\
\text { Vardöy Ware, Anttila Ware }\end{array}$ \\
\hline Early Iron Age (Litorina Sea) & $500 \mathrm{cal} \mathrm{BC}-300 \mathrm{cal}$ AD & $\begin{array}{l}\text { Clear signs of cereal cultivation according to } \\
\text { archaeobotanical (Vanhanen and Koivisto, 2015) } \\
\text { and palynological finds (Vuorela, 1999) }\end{array}$ & $\begin{array}{l}\text { Morby Ware, Sirnihta Ware, Luukonsaari Ware, } \\
\text { Kjelmöy Ware }\end{array}$ \\
\hline
\end{tabular}

Finland was first colonized during the Mesolithic period (c. 8900-5200 cal BC), beginning about 500-600 years after the Scandinavian Ice Sheet had melted in the region (e.g. Jussila et al., 2012; Sørensen et al., 2013; Pesonen et al., 2014; Tallavaara et al., 2014). Foraging strategies prevailed during the Mesolithic period (Matiskainen, 1989).

The beginning of the Neolithic period is demarcated by the appearance of the first ceramics in the east, deriving from the area of modern Russia (Carpelan, 1999, 2002; Piezonka, 2014). Different regional and chronological varieties of Comb Ceramics and Asbestos Ceramics were used during the Neolithic (e.g. Carpelan, 1999, 2002; Mökkönen, 2011; Pesonen et al., 2012). However, in northern Finland, the production and use of clay vessels ceased for over two millennia (c. 4400-1800 cal BC) after the Säräisniemi 1 period (Carpelan, 1999; Torvinen, 2000). Eastern connections were markedly visible during the Typical Comb Ware period (c. 3900-3500 cal BC; e.g. Meinander, 1984; Tallavaara et al., 2010).
Plant cultivation played a minor role in subsistence during most of the Neolithic. According to palynological studies, sporadic and small-scale cultivation was carried out already in the beginning of the Neolithic (Alenius et al., 2013) and continued also later on (Mökkönen, 2010). These palynological results have not yet been backed up by any archaeobotanical remains and their validity as an indicator for cultivation has been questioned (Lahtinen and Rowley-Conwy, 2013). The oldest dated barley grain is AMS dated to the transition from the Late Neolithic to the Bronze Age (Vuorela and Lempiäinen, 1988). According to lipid analyses, the Corded Ware culture kept dairy animals (Cramp et al., 2014) and the first bones of domestic animals derive from the Kiukainen culture (2400-1900/1500 BC) (Bläuer and Kantanen, 2013).

Agriculture became more important during the Bronze Age (Holmblad, 2010; Vanhanen and Koivisto, 2015) and ceramic production re-emerged during this period in northern Finland (Carpelan, 2003, 2004). The appearance of iron c. 500 cal BC did not

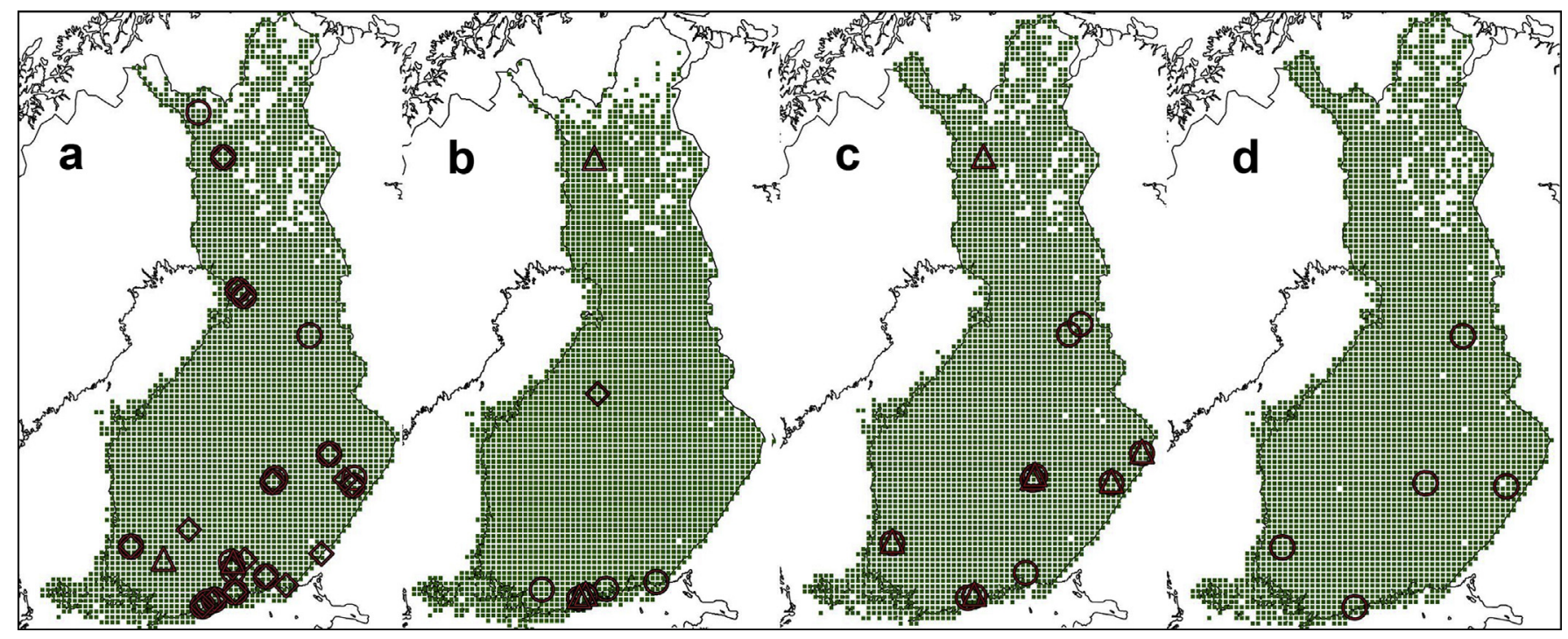

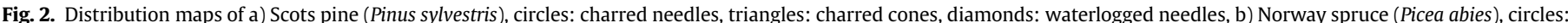

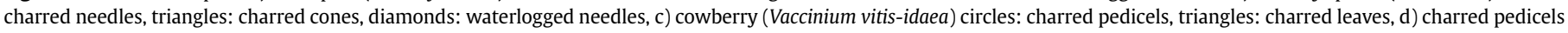
of bilberry (Vaccinium myrtillus). Current distributions of the species are marked with squares (data from Lampinen et al., 2014). 


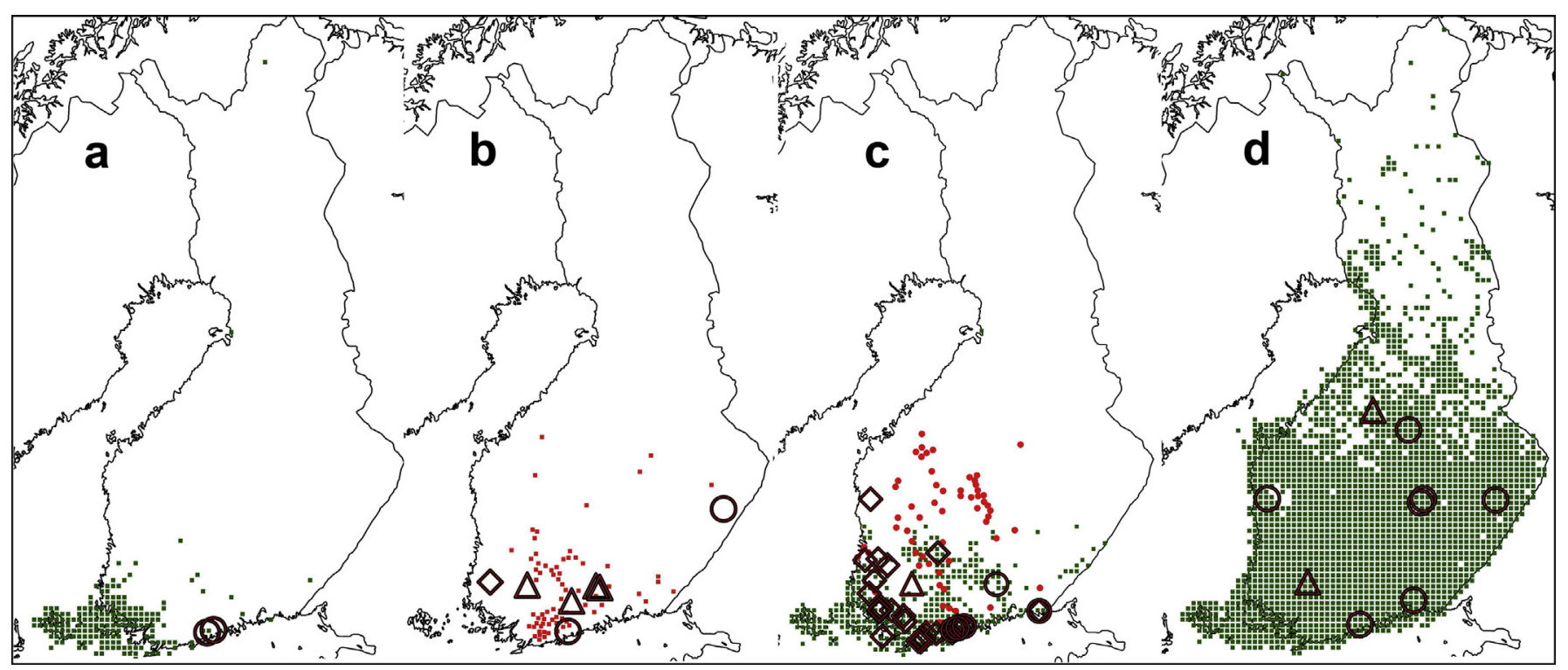

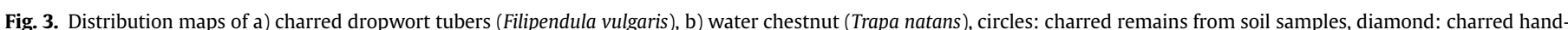

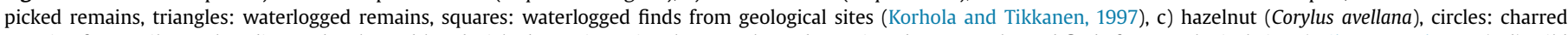

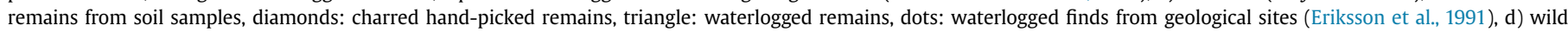

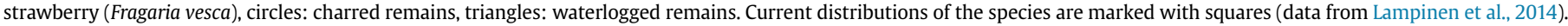

mark a complete change in the economy. Foraging prevailed until early historical times alongside with the productive economies, but the manufacture of ceramics ceased c. $300 \mathrm{cal} \mathrm{AD}$ in the inland regions (e.g. Carpelan, 1999).

\subsection{Holocene vegetation development}

Holocene vegetation development varied in different parts of the country (Korhola, 1990). According to pollen analyses, Norway spruce (Picea abies) entered Finland from the east around $4500 \mathrm{cal} \mathrm{BC}$ (Seppä et al., 2009). The earliest postglacial vegetation consisted mostly of herbaceous species, which were followed by forests dominated by birch (Valste et al., 2006). The dominance of birch continued in northern Finland, but was followed by a dominance of pine in the south (Valste et al., 2006). During the Holocene thermal maximum, which prevailed c. (6000-2000 cal BC), mixed oak forests, other thermophilous taxa, and pine forests were growing further up north than today (Korhola, 1990; Ojala et al., 2008; Seppä et al., 2015) and were more abundant in southern Finland (Tallavaara and Seppä, 2011). This has been studied lately with special reference to hazel (Corylus avellana), which grew further north than today (Seppä et al., 2015, see also Fig. 3c). The Holocene thermal maximum was followed by an overall retreat of thermophilous species towards the south (Korhola, 1990).

\section{Material and methods}

\subsection{Data collection}

Data from archaeobotanical analyses and hand-picked plant remains of the Finnish Stone Age were collected from publications and reports (Kulttuuriympäristön rekisteriportaali). Analysed soil samples without plant remains were excluded. Sites classified as settlements and graves were included in the list of charred plant remains.

Many sites span long periods of time and contain mixed contexts. Therefore we discuss wild plant gathering for food during the whole of the Stone Age in Finland as opposed to specific periods.
Due to the varying amounts of plant material at different sites and different sampling strategies, it was difficult to assess the importance and possible uses of the plants found. We used charred plant remains, with a large geographical and temporal spread, as a starting point for our analysis, and combined this data with waterlogged and hand-picked material.

Data was compiled and divided into three categories: Appendix A contains archaeological site information and hand-picked material, Appendix B contains charred plant remains, and Appedix C contains waterlogged plant remains.

Appendix A - Site information and hand-picked material contains the site name, period, ceramic types, excavation years, type of plant material found, coordinates for the site, and selected references on the site. The dating of the sites is based on radiocarbon dates and ceramics. In defining the ceramic finds, the database of Finnish Archaeological Artefacts was applied (Sundell and Onkamo, 2010; Pesonen and Sundell, 2011; Sundell et al., 2014), together with online reference material of Finnish prehistoric ceramics (Pesonen, 1999) and published literature. The database is not public yet, but basically it contains the same information as the find catalogues stored in the Archives of the National Board of Antiquities. Ceramics form the main basis for the periodization of the Neolithic Stone Age, while radiocarbon dates play a more prominent role for the Mesolithic. Only published radiocarbon dates were used. They are not listed in this paper, but references are given in Appendix A. The sites are usually dated broadly, and a more accurate context dating of the archaeobotanical samples has not been attempted. Only a small number of radiocarbon dates are obtained from the actual plant remains. Most of the radiocarbon datings derive from charcoal and burned bone. Hand-picked material was collected from Luoto's (1991) review and newer sites from the database of Finnish Archaeological Artefacts (Sundell and Onkamo, 2010; Pesonen and Sundell, 2011). The presence of a species was noted, but not the quantity of remains.

A large proportion of the hand-picked archaeobotanical material kept in the collections of the National Museum of Finland was reidentified for this paper in order to ensure that identifications of hazelnut and water chestnut were correct. Our aim was to check 
whether the northernmost sites actually contained hazelnuts and also to ensure the quality of the other identifications. The identification was done at the National Board of Antiquities in Helsinki by the authors with the aid of a stereo microscope. This reinspection by the authors showed that finds identified as hazelnuts from a number of sites in the find catalogue referred to in the Archaeological Artefacts Database and in the list provided by Luoto (1991) did not, in fact, consist of hazelnuts, but of charcoal or other unidentified material. Reidentified remains that were still considered as hazelnut shells or water chestnut remains by the authors are marked with an $\mathrm{x}$ in the "studied" column in Appendix A. Remains that were reidentified as something other than hazelnuts or water chestnuts are listed in the description of Appendix A. As a result, the northernmost find site of charred hazelnut shifted from Kemijärvi Haveri in southern Lapland to Kristiinankaupunki Rävåsen in coastal Ostrobothnia.

Appendix B - List of charred plant remains contains the periodization of the sites, sample amount, sample volume, quantity of plant remains per site, and plant identifications. Indeterminate (indet.) remains are not included. Uncertain identifications (cf.) are grouped together with certain identifications. In most cases, the amount of plant remains was mentioned in the reports, but sometimes only their presence was noted, which is marked in the appendix with italics.

Appendix C - List of waterlogged plant remains contains the periodization of the sites, sample amount, sample volume, quantity of plant remains, and plant identifications. The presence of a plant taxon is marked in italics. The majority of the studied waterlogged assemblages are from stratigraphic sequences and only layers dated to the Stone Age are included in this review. These layers contained archaeological finds or were taken from the vicinity of archaeological sites. All of them are not settlement layers sensu stricto, but are connected to human activities. They all have been situated on ancient bodies of fresh water, which have later turned into dry land. In this sense they differ from the charred material and should not be directly compared with waterlogged material from Stone Age dwelling sites elsewhere, such as the Neolithic sites of the eastern Baltic (e.g. Berihuete Azorin and Lozovskaya, 2014).

\subsection{Ethnographic and historical sources used in the study}

We surveyed ethnographic and historical literature and old floras in order to find out possible uses for plants found at Stone Age sites in Finland. The survey was limited in ethnographic accounts from the area of Finland, where the flora has remained more or less similar from prehistoric to historical times and there might have been a local historical continuity in the use of wild plants. Also archaeobotanical literature is used to suggest prospective uses for plants. Our aim is to find out any ways in which the most common plants in Stone Age Finland could have been used for food. We acknowledge that plants were used also for other purposes than food and that different parts of the same plant could be used for different purposes. However, our principal aim is to find out how the plants occurring at Stone Age sites could have been consumed and prepared for food and especially how they ended up in charred assemblages.

The use of wild plants for food is discussed briefly in ethnographical works describing the traditional culture of the 19th and 20th centuries in Finland (Vuorela, 1975; Talve, 1977; Sirelius, 1989) and more broadly in a work describing the habits of the FennoUgric tribes (Manninen, 1934). An ethnographical study by Hautala (1964) concentrates on the use of berries in Finland. Hautala's ethnographical sources date mostly between the 1920s and 1940s and only partly to the last decades of the 19th century (Hautala, 1964:1). Plant foods used in Finnish Lapland by the Sami have been discussed by Itkonen $(1921,1984)$ and those used in the Circumpolar area by Eidlitz (1969). Plant use in the area of Karelia situated in eastern Finland and Russia is described by Manninen (1932). The use of plants for medicine, food, and other purposes during the 18th century in the former district of Satakunta is elaborated by Gadd (1751). Plants used by Finns in emergency bread at the end of the 17th and during the 18th century are listed by Wallenius (1782). Wild plants reported in these studies can be categorized into berries, vegetables, seeds, roots, and the inner bark of pine.

Many berries (in the vernacular meaning) have been used for food, and their various uses have been described in detail by Hautala (1964). She describes how berries were preserved, mixed uncooked with other foods, boiled, baked in the oven, used in pastries, and made into beverages. The most commonly gathered berries with many different uses were cowberries (Vaccinium vitisidaea) in southern Finland (Talve, 1977:15) and crowberries (Empetrum nigrum) together with cloudberries (Rubus chamaemorus) in northern Finland (Itkonen, 1984:254). Many other edible berries were collected from the wild: wild strawberries (Fragaria vesca), bilberries (Vaccinium myrtillus), bog bilberries (Vaccinium uliginosum), raspberries (Rubus idaeus), stone brambles (Rubus saxatilis), bird cherries (Prunus padus), and rowan berries (Sorbus aucuparia), as well as other berries from time to time (Hautala, 1964:4). Also blackcurrants (Ribes nigrum) and 'redcurrants' (Ribes spicatum/rubrum) were used (Gadd 1751:97).

The use of 'greens' is discussed in less detail. In the Sami area, garden angelica (Angelica archangelica) has been important and used in various ways (Itkonen, 1921:78-79). The Sami mixed leaves and other green parts of plants with milk. Plants used included sheep's sorrel (Rumex acetosella), mountain sorrel (Oxyria digyna), Mulgedium sp., wolf's-bane (Aconitum lycoctonum), Ribes sp., rosebay willowherb (Epilobium angustifolium), and lady's mantle (Alchemilla sp.) (Itkonen, 1921:79-80). Chives (Allium schoenoprasum) growing especially on shores were used as seasoning in salmon soups, and a scurvy-grass species (Cochlearia arctica) was used by the Sami for an unknown purpose (Itkonen, 1921:80). Green parts of Rumex, hemp-nettles (Galeopsis sp.), sow-thistles (Sonchus sp.), dead-nettles (Lamium sp.), thistles (Cirsium sp.), nettle (Urtica sp.), and sometimes also blackcurrant (Ribes nigrum) were used as greens or as an ingredient in emergency bread (Gadd 1751:96; Wallenius 1782). Peeled stalks of wild angelica (Angelica sylvestris) and parts of horsetail (Equisetum sp.) were eaten by Finns (Manninen, 1934:146).

The use of wild seeds seems to have been limited. Emergency bread was baked from the seeds of common club-rush (Schoenoplectus lacustris), lyme-grass (Leymus arenarius), common sorrel (Rumex acetosa), and knotgrass (Polygonum aviculare) (Wallenius 1782).

The roots of Polygonatum, probably angular Solomon's-seal (Polygonatum odoratum), bogbean (Menyanthes trifoliata), alpine bistort (Bistorta vivipara), bog arum (Calla palustris), and Convallaria, meaning most probably lily-of-the-valley (C. majalis), were baked as emergency bread in different parts of southern Finland (Wallenius 1782; Gadd 1751). Fresh peeled roots of Scandinavian small-reed (Calamagrostis purpurea) and peeled roots of polypody (Polypodium vulgare) were eaten by the Sami (Itkonen, 1921:80).

The inner bark of Scots pine has been used in abundance by the Sami (Itkonen, 1921) and also in southern Finland for emergency bread (Wallenius 1782). The methods, tools, gathering period, suitable trees, and dishes for preparing the inner bark of Scots pine 
used by the Sami are elaborately discussed, for example, by Itkonen (1921:73-77). The Sami also used to chew the resin of Norway spruce (Pinus sylvestris) and drink birch sap (Betula sp.) (Itkonen, 1921:77-78).

In addition to the ethnographical material, the use of many different wild plants is discussed by Lönnrot and Sælan in their Finnish Flora (1866) and by Palmstruch in his Swedish Flora (Palmstruch, 1802-1843). Around 600 plants are listed in Catalogus Plantarum by Til-Landz (1683), who mainly discusses their medicinal uses.

We used Regnell's (2011) criteria for the utilization of wild plants as applied to archaeological material. He proposes that a wild plant can be considered as utilized by humans if it fulfils at least one of the following criteria: 1 ) it occurs in very large quantities in the find material, 2) it is present in an exotic environment (such as aquatic plant on dry land), and 3 ) it shows obvious signs of human processing.

\section{Results and discussion}

\subsection{The quantity of plant material at Stone Age sites}

In total, 43 sites with soil samples containing charred plant remains are included in our analysis (Appendix B). These sites are relatively evenly distributed throughout Finland (Fig. 1b). The total number of studied soil samples is 724 and the total volume of studied samples exceeds 1960 L (sample volume was not mentioned in all cases).

Altogether 2983 identified plant remains were found. Of these, 1789 were seeds and other propagules and 1194 were other plant parts: catkins, stalks, pedicels, roots, tubers, needles, cones, and leaves. The number of different taxa was 103, consisting of 88 seeds and 15 other plant parts.

The amount of plant remains varied between sites (Table 2). Some sites contained only very few remains and other sites contained relatively rich assemblages. Plant densities are usually low at northern European Neolithic sites (Kirleis and Klooß 2014), and our results seem to be in line with them.
Table 2

Quantity of charred remains in the samples.

\begin{tabular}{lccc}
\hline & Min & Max & Average \\
\hline Remains/site & 1 & 379 & 69.4 \\
Seeds and fruits/site & 1 & 191 & 41.6 \\
Seeds and fruits/litre & $<0.1$ & 11.7 & 1.9 \\
Seeds/sample & $<0.1$ & 38.5 & 4.2 \\
All remains/litre & $<0.1$ & 35.2 & 4.2 \\
All remains/sample & 0.1 & 44.8 & 6.5 \\
Ubiquity of all taxa & 1 & 25 & 7.8 \\
Ubiquity of seed taxa & 0 & 22 & 5.8 \\
\hline
\end{tabular}

Charred hand-picked material has been found at various Stone Age sites (Appendix A): 34 sites have yielded charred hazelnut (Corylus avellana) shells, two sites charred water chestnut (Trapa natans) remains and one site charred crab apples (Malus sylvestris).

Seven sites have yielded waterlogged plant remains dating to the Stone Age (Appendix C). These sites are situated in southern Finland, and three of them are near each other in the LahtiOrimattila region. Where information is available, the soil volume and sample amount have been small. Only vertical stratigraphy has been studied, thus revealing no information on the horizontal spread of plant remains. More than 3950 individual plant remains were found in the Stone Age layers at these sites. These finds consist of 97 different taxa. The number of plant remains per site varied between 248 and 1465. A large proportion of the plants is aquatic or thrive on shorelines, and four of the sites contain water chestnut. Many trees and some dryland plants thriving in the vicinity of human settlement have been found.

\subsection{Most common plant remains}

The majority of the charred plant taxa consists of edible plants or plants that could have been used for other purposes. As all taxa cannot be reasonably discussed in this paper, we have chosen to discuss here the most common charred taxa. We also include water chestnut, which has been widely used by Stone Age people and has often been found at sites with waterlogged material.

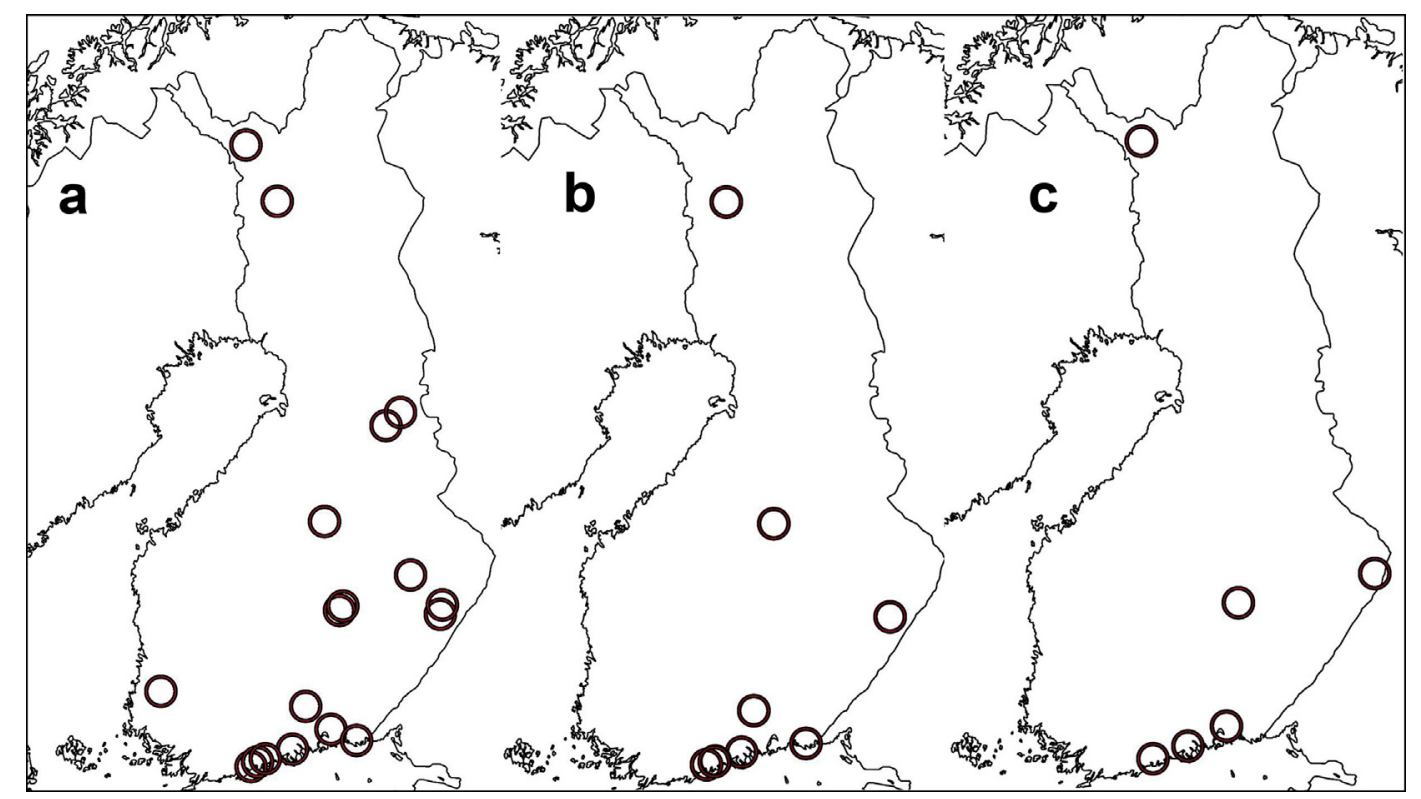

Fig. 4. Distribution maps of species identified to a higher taxon. Charred remains of a) grasses (Poaceae), b) sedges (Carex sp.), c) docks or sorrels (Rumex sp.). 
Table 3 presents charred taxa occurring at five or more sites and/ or with more than 50 plant remains (water chestnut also included). The plants are categorized into seeds and fruits and other types of plant remains. The amounts of waterlogged remains of the taxa in question are included in the table. found and identified during archaeological excavations (Hather and Mason, 2002:7-8) than smaller and less well preserved plant remains.

Water chestnut (Trapa natans) grows in nutrient-rich freshwater basins or brackish waters at depths of $0.3-3.6 \mathrm{~m}$ (Hummel and

Table 3

The most common seeds and other plant remains. Ubiquity stands for presence on a site.

\begin{tabular}{|c|c|c|c|c|}
\hline & Charred ubiquity, 43 sites & Charred total & Waterlogged ubiquity, 7 sites & Waterlogged total \\
\hline \multicolumn{5}{|l|}{ Seeds and fruits } \\
\hline Grass (Poaceae) & 21 & 151 & 4 & 8 (many species) \\
\hline Bearberry (Arctostaphylos uva-ursi) & 18 & 279 & - & - \\
\hline Raspberry (Rubus idaeus) & 18 & 105 & 2 & 13 \\
\hline Juniper (Juniperus communis) & 10 & 37 & 2 & 2 \\
\hline Crowberry (Empetrum nigrum) & 10 & 147 & 1 & 7 \\
\hline Hazel (Corylus avellana) & $9+34$ hand-picked & 371 & 1 & 2 \\
\hline Carex sp. & 9 & 34 & 7 & 882 (many species) \\
\hline Fat hen (Chenopodium album) & 7 & 83 & - & - \\
\hline Wild strawberry (Fragaria vesca/cf. F. vesca) & 7 & 12 & 2 & 24 \\
\hline Rumex sp. & 6 & 25 & 1 & $1($ R. acetosa $)$ \\
\hline Viola sp./cf. Viola sp. & 6 & 7 & 1 & 9 \\
\hline Cereals (Cerealia/cf. Cerealia) & 5 & 71 & - & - \\
\hline Bird cherry (Prunus padus) & 5 & 18 & 1 & 1 \\
\hline Sheep's sorrel (Rumex acetosella) & 5 & 5 & - & - \\
\hline Yellow water-lily (Nuphar lutea) & 3 & 133 & 5 & $>49$ \\
\hline Water chestnut (Trapa natans/cf. Trapa natans) & 2 & 4 & 5 & $>1582$ \\
\hline \multicolumn{5}{|l|}{ Other plant remains } \\
\hline Scots pine needle (Pinus sylvestris) & 21 & 593 & 2 & 3 \\
\hline Scots pine cone (Pinus sylvestris) & 18 & 74 & - & - \\
\hline Cowberry pedicel (Vaccinium vitis-idaea) & 10 & 41 & - & - \\
\hline Norway spruce needle (Picea abies) & 8 & 324 & 1 & 114 \\
\hline Cowberry leaf (Vaccinium vitis-idaea) & 7 & 36 & - & - \\
\hline Bilberry pedicel (Vaccinium myrtillus/cf. V. myrtillus) & 5 & 15 & - & - \\
\hline Dropwort tuber (Filipendula vulgaris) & 3 & 62 & - & - \\
\hline
\end{tabular}

Plant habitats were not studied in detail, but the most common plants can be categorized into the following habitat types (HämetAhti et al., 1998): 1) plants thriving on shores or in mesic forests (Chenopodium album and Prunus padus), 2) aquatic plants (Nuphar lutea and Trapa natans), and 3) plants typical of boreal heath forests (Empetrum nigrum, Pinus sylvestris, Vaccinium vitis-idaea, Picea abies, and Vaccinium myrtillus). Fat hen (Chenopodium album) can grow on shores or in anthropogenic habitats. Many of the plants also thrive in anthropogenic and open habitats (Rubus idaeus, Juniperus communis, Corylus avellana, Fragaria vesca, and Filipendula vulgaris).

\subsection{Possible uses for the most commonly occurring plants}

\subsubsection{Nuts}

Hazelnuts (Corylus avellana) could be eaten raw or they could be roasted, boiled in soups, cooked into mash, or baked into bread (Bishop et al., 2013:37). Oil can be extracted from the nuts (Lönnrot and Sælan, 1866). Roasting might improve their taste and preservation (Holst, 2010; Bishop et al., 2013). Nuts could be preserved for the winter in deep sand pits surrounded by moss and covered with birch bark, sand, and grass turf (Palmstruch, 1802-1843). The two main reasons suggested for the nutshells becoming charred are roasting and fuel use (Bishop et al., 2013:37-39; Kubiak-Martens, 1999). We found no ethnographic uses for hazelnuts in Finland, even though they are said to be well known by Lönnrot and Sælan (1866).

Hazelnuts are the most common plant finds from Mesolithic Scandinavia (Regnell, 2011:12) and are discussed frequently in Stone Age contexts. Nuts are calorific and are considered to have been an important part of subsistence during the Mesolithic period (e.g. Mithen et al., 2001; Holst, 2010; Regnell, 2011). However, this view might be biased because these large nuts are more easily
Kiviat, 2004). Water chestnut thrives in an alkaline substrate. During the Stone Age, it grew, for example, in eutrophic lakes together with large amounts of Nuphar, Nymphaea, and Potamogeton natans (Vuorela and Aalto, 1982). The plant requires a water temperature of $12{ }^{\circ} \mathrm{C}$ in May and high temperatures in July (Vuorela and Aalto, 1982 and literature cited). The currently prevailing climate in Finland does not meet these requirements (Vuorela and Aalto, 1982), but water chestnut remains have still been found in Finland in layers post-dating the Holocene thermal maximum, at the latest c. 600 cal BC (Korhola and Tikkanen, 1997). It has been suggested that water chestnut formerly grew in basins that have place names (toponyms) related to butter or oil (Ahlqvist, 2007). The dating and cause of the extinction of water chestnut in Finland are not very well known, but the overgrowth and acidification of lakes have been proposed as causes for its disappearance (Korhola and Tikkanen, 1997). Climate change does not seem to have been the only cause of extinction, because, as mentioned above, the plant grew in Finland also after the Holocene thermal maximum.

Water chestnut has been found at various prehistoric sites in Europe and beyond, and it is already present in Palaeolithic contexts in Israel (Goren-Inbar et al., 2002). Roasting improves preservation and makes it easier to open the nut shells (Karg, 2006:129). Nuts are harvested in the autumn and they can be stored for winter (Berihuete Azorin and Lozovskaya, 2014). Seeds can be eaten raw or cooked and prepared as flour (Aalto et al., 1985). The starchy and oily nuts have a high calorific content (Tolar et al., 2011), and thus form a desirable food staple. Broken fruit fragments found at the waterlogged archaeological sites of Humppila Järvensuo and Orimattila Pennala have been interpreted as having been crushed by humans (Aalto, 1983:90). Wooden mallets, such as those found at the waterlogged site of Sārnate in the eastern Baltic, were used for cracking the nuts open (Bērzinšs, 
2008:464). We found no ethnographic accounts for the use of water chestnut in Finland. This lack was expected due to the early extinction of the species in Finland.

\subsubsection{Berries}

Bearberries (Arctostaphylos uva-ursi) have not been commonly consumed in Finland and are not discussed by Hautala (1964). However, according to Palmstruch's account from the early 19th century, raw berries were eaten by, "the Sami, Russians, and poor people and the berries can be cooked into syrup" (Palmstruch, 1802-1843). Bearberries could have been important during the winter, because berries remain attached to the plants and could have been collected under snow (Turner et al., 2011). The leaves and stalks of the plant have been used for tanning (Lönnrot and Sælan, 1866; Palmstruch, 1802-1843).

Raspberries (Rubus idaeus) can be eaten raw, and ethnographic accounts relate that they have occasionally been preserved by drying in Finland (Hautala, 1964:16; Lönnrot and Sælan, 1866:324). Raspberries are rather common Stone Age finds. They have been found, for example, in Sweden (Regnell, 2011), Denmark (Robinson and Harild, 2002), and alpine settlements (Maier and Harwath, 2011). Large amounts of raspberry seeds were found mostly in the stomach area of a Neolithic skeleton discovered in a moss in southern Sweden (Gejvall et al., 1952). Waterlogged raspberry seeds found at Humppila Järvensuo were fragmented, and it has been suggested that they have been chewed by humans (Aalto et al., 1985).

The fleshy cones of juniper (Juniperus communis) have been used especially for making beverages in Finland (Hautala, 1964:81; Lönnrot and Sælan, 1866:367). Beverages could be prepared, for example, by mixing the cones with water (Hautala, 1964:81). Juniper cones and needles could have been smoked inside to prevent diseases (Lönnrot and Sælan, 1866:367). Branches and needles have been used for smoking fish and meat (Palmstruch, 1802-1843).

Crowberry (Empetrum nigrum) is distributed throughout Finland, but it is more common in northern parts of the country, where also the subspecies hermaphroditum is more abundant, while the subspecies nigrum is more common in the southern parts of the country (Lampinen et al., 2014). The bigger and juicier berries growing in Lapland were collected in large quantities by the Sami (Itkonen, 1921:82). Crowberries could be collected during the winter and were often used after they had frozen. The Sami had various uses for crowberries. The berries were mixed with reindeer milk and stored for the winter in dried sheep guts. It is suggested that charred crowberry seeds might be leftovers from food preparation or from a ritual offering of food (Viklund, 2011:193). Archaeobotanical finds of crowberry seeds are common in northern Scandinavia (Viklund, 2011:194).

Palmstruch (1802-1843) maintains that wild strawberry (Fragaria vesca) fruits are best consumed raw. The berries have occasionally been dried for preservation in Finland (Hautala, 1964:16). Large amounts of wild strawberry seeds in Stone Age alpine settlements have clearly shown that these berries were gathered from the wild (Maier and Harwath, 2011:361). The consumption of wild strawberries is also indicated by seeds from the site of Humppila Järvensuo. These seed finds are considered to have been chewed (Aalto et al., 1985).

Berries of the bird cherry (Prunus padus) have been used especially in Russia (Hautala, 1964:79). Large quantities of uncharred bird cherry seeds were found at a medieval settlement in Siberia, where the seeds were crushed into fragments and in one case collected into a box made out of birch bark (Korona, 2014).

Cowberry (Vaccinium vitis-idaea) and bilberry (Vaccinium myrtillus) have been commonly used in Finland and are traditionally used and preserved in various ways (Hautala, 1964). They both were used in preparing emergency bread (Wallenius 1782). Cowberries were preserved by cooking and drying, as well as in vessels simply with cold water poured over them (Hautala, 1964:6-12). In the first half of the 20th century, cowberries were fried on heated stone slabs or in clay pots in an oven (Hautala, 1964:66-67). This type of food was eaten especially by shepherds and children, and in some cases, cowberries were eaten in this manner before they were ripe (Hautala, 1964:67). Bilberries were mostly preserved by drying, but sometimes also by cooking with salt and water (Hautala, 1964:12-14). Even though the most common Stone Age remains of cowberry and bilberry are pedicels, also some remains of seeds of different Vaccinium species have been found.

\subsubsection{Plants with edible seeds}

Fat hen (Chenopodium album) may have been used as a vegetable, and its seeds can be eaten (Robinson, 2007:363; KubiakMartens, 1999).

Chenopodium seeds have been found both in the intestines of various Iron Age bog bodies in northern and central Europe and in large assemblages at Iron Age and Stone Age sites (Behre, 2007). It is considered to have been a gathered plant during the Neolithic (e.g. Antolín and Jacomet, 2015).

We did not find ethnographic accounts on the use of the seeds of the yellow water-lily (Nuphar lutea) in Finland. This plant is considered toxic for pigs by Palmstruch (1802-1842).

In Ireland, large amounts of charred water-lily seeds have been proposed as being the remains of seed processing or storage (Warren et al., 2013). Water-lilies could also have been considered weeds that were deliberately removed in order to provide water chestnut with a competitive advantage (Bērzinšs, 2008:347). On an island near Narva in Estonia, water-lily roots were made into bread together with pine bark in 1709 (Wallenius 1782).

Most of the charred grass seeds in the find material studied are identified only to the grass family (Poaceae). Many wild species of the grass family have edible parts. This is indicated, for example, by the ethnographical use of lyme-grass (Leymus arenarius) seeds in emergency bread in Finland (Wallenius 1782) and by the use of the roots of Scandinavian small-reed (Calamagrostis purpurea) by the Sami (Itkonen, 1921:80). Also sweet-grass (Glyceria sp.), found in Stone Age contexts in Scandinavia, is considered to have been consumed (Robinson, 2007:363). There is thus some ethnographic evidence for the food use of grass species.

The use of different Rumex species (and their close relatives) is relatively well documented in Finland. The Sami used sheep's sorrel (Rumex acetosella) and mountain sorrel (Oxyria digyna) with milk (Itkonen, 1921:79-80), and the seeds or whole plants of common sorrel (Rumex acetosa) were used in emergency bread in southern Finland (Wallenius 1782). Some of the Stone Age charred remains from Finland are identified as $R$. acetosella.

Also the seeds of some Carex species might have been consumed, but due to their imprecise identification and lack of ethnographical use in Finland, they are not discussed here.

\subsubsection{Plants with edible roots}

Several types of roots were eaten in emergency bread in southern Finland and in other ways by the Sami (Wallenius 1782; Itkonen, 1921). Often these roots were pounded or ground (Wallenius 1782), which makes it difficult to discover them with traditional archaeobotanical methods. They might be identified by studying fragments of parenchyma found in the soil samples (Mason et al., 2002).

Root foods are represented in our material by finds of dropwort root tubers (Filipendula vulgaris). In Finland, natural stands of dropwort can produce 4-25 tubers with a mean size of $c$. $25 \times 9 \mathrm{~mm}$ (Lempiäinen, 1978). It has been suggested that 
dropwort has an anthropogenic origin in Finland. It has been used in emergency bread (Palmstruch, 1802-1843). Dropwort root tubers have also been found in Iron Age graves in Sweden (Engelmark, 1984).

\subsubsection{Scots pine and Norway spruce}

It is not clear why needles and cones of Scots pine (Pinus sylvestris) and Norway spruce (Picea abies) are found in the archaeobotanical samples. Even though the inner bark of pine could have been consumed, the finds of needles and cones are not clear indicators of consumption. The use of the inner bark for food has been considered difficult to study with archaeobotanical methods (Lempiäinen, 1997:43). However, Scots pine trees with cutting marks dated with dendrochronology and radiocarbon have shown that inner bark was collected for food at least during the 17th century in Finnish Lapland (Bergman et al., 2004) and already around 1000 BC in Swedish Lapland (Östlund et al., 2003). Tree bark has not been identified in the analyses discussed in this paper. Bark has, however, been found at Danish Stone Age sites, and the identification of the bark remains might be a way to identify use of the inner bark for food (Mason et al., 2002:193).

\subsection{Distribution of the most common Stone Age plant remains compared with their current distribution}

Finds of the common Stone Age plant remains (Table 3) were correlated with the current distribution of the same species in Figs. 2-6. Current distributions are retrieved from on-line distribution maps of vascular plants in Finland, which are up to date and have been collected since the 1960s by the Finnish Museum of Natural History (Lampinen et al., 2014). Current distribution maps may contain inaccuracies (Lampinen et al., 2014), but they certainly show the overall distribution of the species. Genus or family level identifications were not compared with current distributions. It should be noted that plants could have been transported or traded, and thereby they might not always represent the vegetation in the immediate vicinity of the site.
The distribution maps (Figs. 2-6) indicate that during the Stone Age, the majority of the studied plants were utilized within an area corresponding to the current overall distribution of the species. Archaeobotanical remains have been found outside their current distribution areas only in two cases: water chestnut (Trapa natans) and hazel (Corylus avellana). Hazel remains have been found at the Middle/Late Neolithic settlement site of Rävåsen, which lies outside the current distribution of hazel (Hertell and Manninen, 2006). Waterlogged remains of both hazel and water chestnut are found in geological layers even further north than archaeobotanical finds. All finds of water chestnut are outside their current distribution, because the species is now extinct in Finland. The lack of nut finds in the northern parts of its ancient distribution area, where waterlogged nuts have been found in geological layers, may be due to inadequate sampling during archaeological excavations.

Even though the Stone Age distribution of hazel and water chestnut were more northern than today, they were both clearly restricted to southern areas. Dropwort (Filipendula vulgaris) is the most southern plant depicted in the maps. Wild strawberry (Fragaria vesca) and bilberry (Vaccinium myrtillus) show an intermediate distribution between north and south. Raspberry (Rubus idaeus) is common, but not found in the northernmost areas.

Scots pine (Pinus sylvestris), crowberry (Empetrum nigrum), bearberry (Arctostaphylos uva-ursi), and grasses (Poaceae) have been found at many sites distributed through the whole country. Fat hen (Chenopodium album), juniper (Juniperus communis), bird cherry (Prunus padus), yellow water-lily (Nuphar lutea), Norway spruce (Picea abies), cowberry (Vaccinium vitis-idaea), Carex species, and Rumex species also seem to be distributed all the way up to the north, but the find amounts are quite small.

These findings show that there is a southern hazel and water chestnut area, which can be connected to the hemiboreal zone (Fig. 1b) or the preceding type of vegetation before the spread of Norway spruce (Picea abies). Moving northwards, there seems to be an intermediate wild strawberry/raspberry zone, where nuts did not grow, but the productivity and biodiversity was still somewhat higher than in the far north. Plants were gathered also in the north,

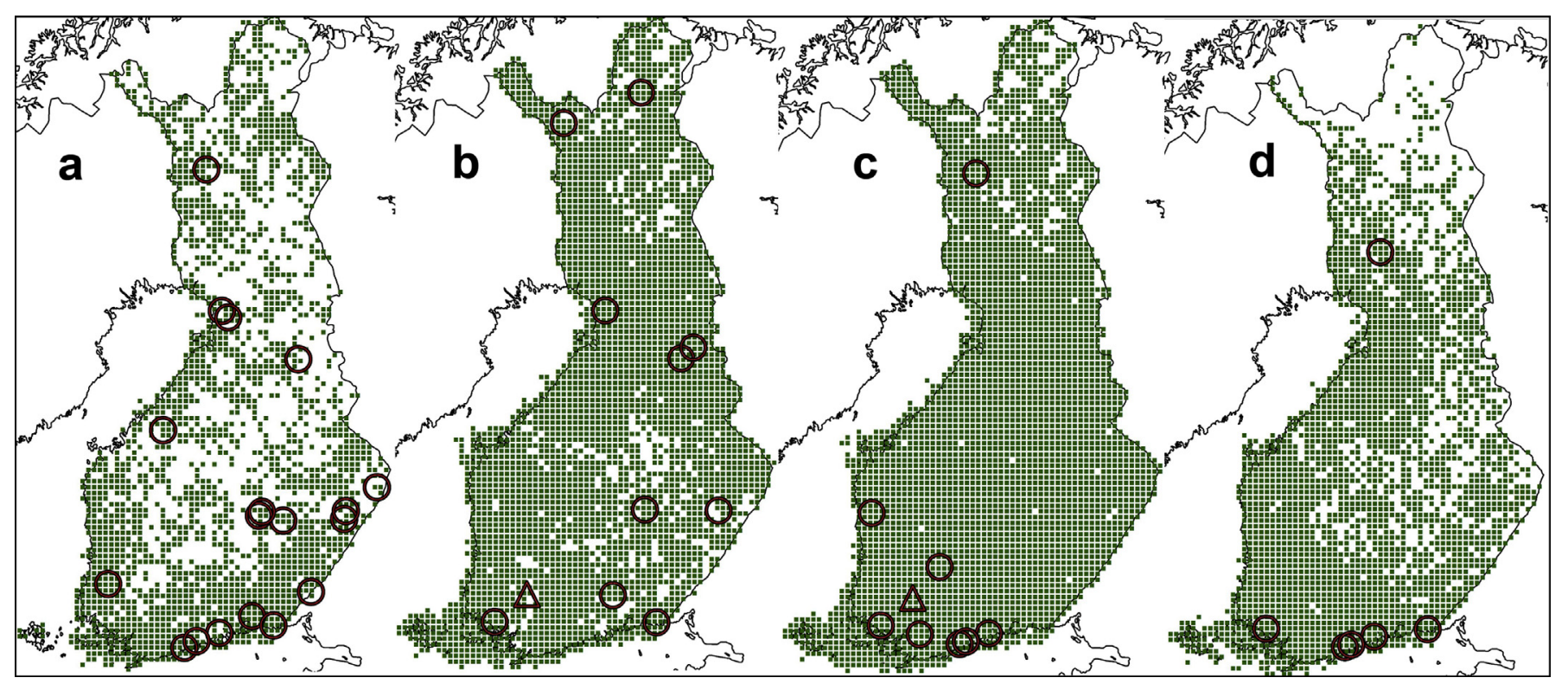

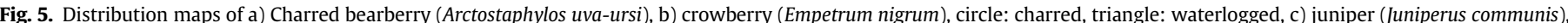

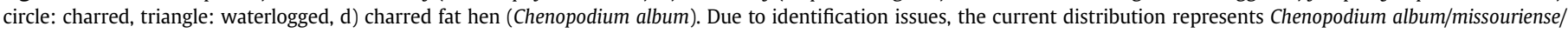
probstii/suecicum (Lampinen et al., 2014). Current distributions of the species are marked with squares (data from Lampinen et al., 2014). 


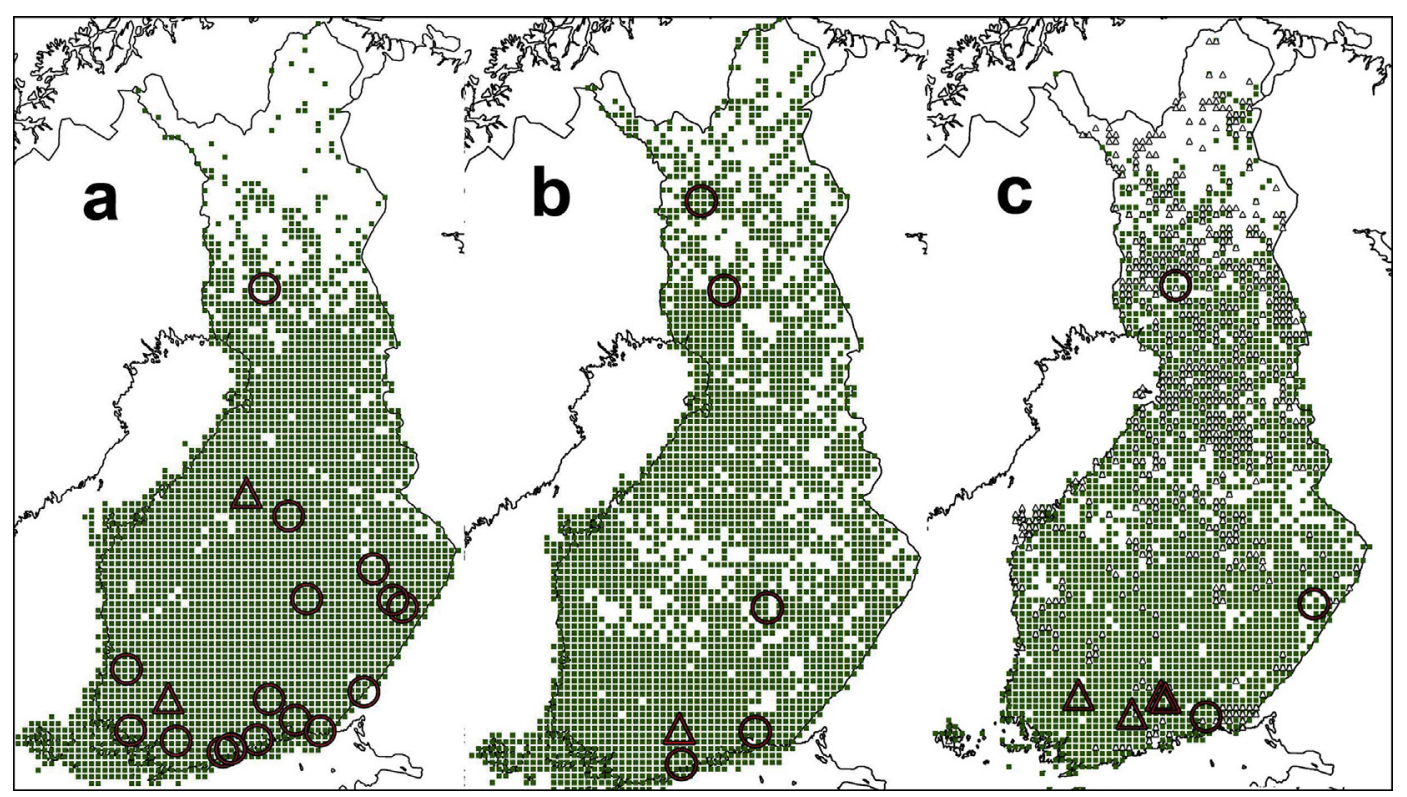

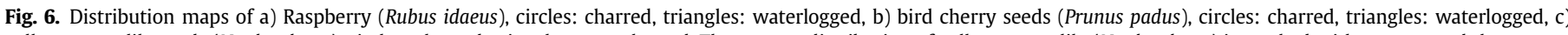

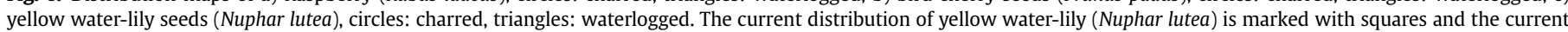

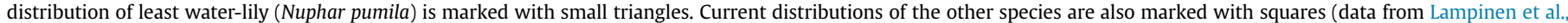
2014).

as illustrated by the finds of various plants in this region (e.g. crowberry, bearberry, and bird cherry).

\subsection{Taphonomy of charred forager plant assemblages}

All plants found in charred assemblages have been processed with fire, which could have been intentional or accidental. Many archaeobotanical samples were collected in or near fireplaces and in refuse pits, where material from fireplaces could have been deposited. Plants could have been a source of fuel in themselves or they could have been burnt among other waste (Van der Veen, 2007). Needles most probably derive from fuel use. At the Rävåsen site, charred hazelnut shells seem to have been discarded outside a house together with burned bones (Hertell and Manninen, 2006), and even stones were cast into the fire at some sites (Manninen and Knutsson, 2014). Cremated bones of fowled gallinaceous birds (Tetrao and Lagopus species) are commonly found in Stone Age contexts in Finland (Mannermaa, 2003). These birds consume berries (Laine, 2002), which could have charred when the guts of these birds were burned as waste.

Many food plants are processed in a way that can lead to their charring (Van der Veen, 2007; Jacomet, 2013). There are some examples of these kinds of activities in the current study. Hazelnuts, water chestnuts, dropwort tubers, and cowberries can be roasted. Juniper can be used for smoking. In addition, many berries were eaten together with meat or fish dishes (Itkonen, 1984:291-293) and the seeds could have been charred along with the preparation of the dish. Archaeological evidence for this type of food preparation has been gained from studying Comb Ceramic food residue at the site of Maarinkunnas in southern Finland. At Maarinkunnas, lipid analyses showed that fatty acids from marine fauna and benzoic acid were present in the food, thereby suggesting a food consisting of seal or fish meat together with berries (Leskinen, 2003:38). It seems evident that many plants could have become charred during food preparation.

The amount of charred plant remains is generally low in archaeological contexts and represents only a minority of the plants used by the Stone Age people (Jacomet, 2013; Colledge and Connolly, 2014). It is also notable that most of the common Stone Age plants discussed in this article are hard seeds, which survive charring better than light plant parts (Hillman, 1981:140). Waterlogged material has great potential for research, but in Finland only a few waterlogged sites have been studied so far. Hand-picked material, consisting mostly of charred hazelnut shells, is a valuable source, but this material gives a skewed picture of plant use during the prehistoric era. Hazelnuts grew only in the southern parts of Finland, and therefore this material does not take into account the diverse uses of plants in the north or other types of plants used in the south. For this reason, studying soil samples with waterlogged and charred archaeobotanical material is essential in order to understand the whole variety of plant gathering.

\section{Conclusions}

In this article, we review Stone Age archaeobotanical data from mainland Finland. The review shows that a diverse set of plant resources was used in Finland during the Stone Age, represented in the find material mainly as charred plant remains. Roasting, smoking, or other methods of plant processing seem to be important reasons for the preservation of charred assemblages. Charred material can also derive from waste management and plants used as fuel.

The Stone Age distribution of plant remains is highly similar to the current distribution of plants with the exception of water chestnut, which has become extinct in Finland. In addition, one site with charred hazelnut shells is located outside the plant's current range. Plant resources varied between the different parts of the country and thermophilous taxa diminished northwards. Hazel, water chestnut, dropwort, and wild strawberry were used in southern Finland. Bearberry, crowberry, Scots pine, Norway spruce, grasses, juniper, bird cherry, raspberry, sedges, fat-hen, yellow water-lily, violets, cowberry, and Rumex species seem to have been used in more or less the whole area of current Finland. 
Ethnographical material gives insights on the possible uses of wild plants. The use of wild plants seems to have lost its importance with the introduction of agriculture in southern Finland, but the knowledge related to wild plant use was not totally lost. Many plants, or at least plant types, found in Stone Age archaeobotanical assemblages were used during the historical period. It would be valuable to study ethnographical sources in more detail to discover more traditional and historical information on the use of wild plants.

Zvelebil (1994:62) suggested that Stone Age people in temperate Europe used mostly nuts, fruits, and roots, and that seeds were used only in minor proportions. Our research shows that nuts were used only in the southern parts of Finland. The use of fruits (berries) was common throughout the country. Only a small amount of data is available for roots, which have been identified only morphologically, as opposed to the identification of cell structures (Kubiak-Martens, 1999; Mason et al., 2002), thus allowing only the identification of dropwort to the species level. It is highly probable that the roots of water-lilies, for example, could have been used, even though these plants are present in our material only as seeds (Table 3 ). The historically well documented use of pine inner bark might be identified in the Stone Age samples by studying the commonly overlooked remains of bark in more detail (Mason et al., 2002). Our findings also indicate the common use of seeds, as shown by the relatively large amount of grasses, waterlilies, fat hen, Rumex species, and Carex species found in the samples. It is difficult to evaluate the importance of the various plant types (cf. Hather and Mason, 2002), and it has been suggested that even single finds of charred plant remains could indicate economic importance (Antolín and Jacomet, 2015). However, our compilation points towards the conclusion that all of Zvelebil's types (nuts, fruits, roots, and seeds) were used in southern Finland and only fruits, seeds, and possibly roots were used in northern Finland.

This review shows that archaeobotanical studies are of great value in the boreal and hemiboreal zones, where hunting and fishing have commonly been assumed to have been more significant than gathering activities. This study also stresses the importance of studying archaeobotanical soil samples, which can offer a much more varied picture of plant use than solely hand-picked large plant remains. The dating of the sites is rather vague, and in order to reach a more accurate chronology for the plant remains, they should be dated with the AMS method.

\section{Acknowledgements}

We would like to thank the two anonymous reviewers for their valuable comments, Dr. Terttu Lempiäinen for handing over archaeobotanical reports and commenting the text, Dr. Raino Lampinen for providing digital data of the current distribution of the plant species, Dr. Teemu Mökkönen for providing material for the study, and Norm Catto and Sarianna Silvonen for the language revision. The authors would also like to thank Dr. Mikael Manninen, Prof. Karin Viklund, Dr. Radoslaw Grabowski, Prof. Mika Lavento, Lic. Phil. Arja Ahlqvist, and Prof. Milton Nuñéz for valuable comments on earlier versions of the article. SV would like to thank the Doctoral School of History and Cultural Heritage for funding this study.

\section{Appendices A-C. Supplementary data}

Supplementary data related to this article can be found at http:// dx.doi.org/10.1016/j.quaint.2015.10.036.

\section{References}

Aalto, M., 1983. Humppilan Järvensuon neoliittisen asuinpaikan makrofossiileista. Karhunhammas 7, 88-95 (in Finnish).

Aalto, M., Siiriäinen, A., Vuorela, I., 1985. Humppila Järvensuo - a preinvestigation for an archaeological and palaeobotanical project in SW Finland. In: Edgren, T., Jungner, H. (Eds.), Proceedings of the Third Nordic Conference on the Application of Scientific Methods in Archaeology, Iskos 5. Suomen muinaismuistoyhdistys, Helsinki, pp. 165-177.

Ahlqvist, A., 2007. The Finno-Ugrian Hydronymic Stem Voi - as a reflex of the former area of distribution of the water chestnut (Trapa natans). In: Nuorluoto, J. (Ed.), Topics on the Ethnic, Linguistic and Cultural Making of the Russian North, 32. Slavica Helsingiensia, Helsinki.

Alenius, T., Mökkönen, T., Lahelma, A., 2013. Early farming in the northern boreal zone: reassessing the history of land use in Southeastern Finland through highresolution pollen analysis. Geoarchaeology: An International Journal 28, 1-24.

Andrén, E., Andrén, T., Kunzendorf, H., 2000. Holocene history of the Baltic Sea as a background for assessing records of human impact in the sediments of the Gotland Basin. The Holocene 10, 687-702.

Antolín, F., Jacomet, S., 2015. Wild fruit use among early farmers in the Neolithic (5400-2300 cal BC) in the north-east of the Iberian Peninsula: an intensive practice? Vegetation History and Archaeobotany 24, 19-33.

Behre, K.E., 2007. Collected seeds and fruits from herbs as prehistoric food. Vegetation History and Archaeobotany 17, 65-73.

Berihuete Azorin, M., Lozovskaya, O., 2014. Evolution of plant use at the wetland site Zamostje 2, Russia: first results. In: Paleoenvironment and Models of Adaptations of Lake Settlements in the Mesolithic and Neolithic of the Forest Zone of Eastern Europe. Russian Academy of Science, Institute for the History of Material Culture, the State Hermitage Museum, pp. 74-79.

Bergman, I., Östlund, L., Zackrisson, O., 2004. The use of plants as regular food in ancient subarctic economies: a case study based on Sami use of Scots Pine Innerbark. Arctic Anthropology 41 (1), 1-13.

Bērziņš, V., 2008. Sārnate: Living by a Coastal Lake during the East Baltic Neolithic Acta Universitatis Ouluensis B Humaniora 86. University of Oulu.

Bishop, M., Church, P., Rowley-Conwy, P., 2013. Seeds, fruits and nuts in the Scottish Mesolithic. Proceedings of the Society of Antiquaries of Scotland 143, 9-72.

Bläuer, A., Kantanen, J., 2013. Transition from hunting to animal husbandry in Southern, Western and Eastern Finland: new dated osteological evidence. Journal of Archaeological Science 40, 1646-1666.

Carpelan, C., 1999. Käännekohtia Suomen esihistoriassa aikavälillä 5100-1000 eKr. In: Fogelberg, P. (Ed.), Pohjan poluilla. Suomalaisten juuret nykytutkimuksen mukaan, Bidrag till kännedom av Finlands natur och folk 153. The Finnish Society of Sciences and Letters, Helsinki, pp. 249-280.

Carpelan, C., 2002. Esihistorian vuosiluvut, ajoitukset ja kronologia. In: Grünthal, R. (Ed.), Ennen, muinoin. Miten menneisyyttämme tutkitaan, Tietolipas 180. Suomalaisen Kirjallisuuden Seura, Helsinki, pp. 18-27 (in Finnish).

Carpelan, C., 2003. Inarilaisten arkeologiset vaiheet. Inarin kunta, Oulu. In: Lehtola, V.-P. (Ed.), Inari - Aanaar. Inarin historia jääkaudesta nykypäivään, pp. 28-95 (in Finnish).

Carpelan, C., 2004. Environment, archaeology and radiocarbon dates. Notes from the Inari Region, Northern Finnish Lapland. ISKOS 13. In: Lavento, M. (Ed.), Early in the North, vol. 5. The Finnish Antiquarian Society, Helsinki, pp. 17-45.

Colledge, S., Conolly, J. 2014. Wild plant use in European Neolithic subsistence economies: a formal assessment of preservation bias in archaeobotanical assemblages and the implications for understanding changes in plant diet breadth. Quaternary Science Reviews 101, 193-206.

Cramp, L.J.E., Evershed, R.P., Lavento, M., Halinen, P., Mannermaa, K., Oinonen, M., Kettunen, J., Perola, M., Onkamo, P., Heyd, V., 2014. Neolithic dairy farming at the extreme of agriculture in northern Europe. Proceedings of the Royal Society B 281, 20140819. http://dx.doi.org/10.1098/rspb.2014.0819.

Edgren, T., 1993. Den förhistoriska tiden. In: Finlands Historia 1Schildts, pp. 9-270 (in Swedish).

Eidlitz, K., 1969. Food and Emergency Food in the Circumpolar Area. In: Studia Ethnographica Upsaliensia 32. Almqvist \& Wiksells boktryckert AB, Uppsala.

Engelmark, R., 1984. Two useful plants from Iron Age Graves in Central Sweden. In: Baudou, E. (Ed.), Archaeology and Environment 2University of Umeå, pp. 87-92.

Eriksson, B., Aalto, M., Kankainen, T., 1991. Hazelnuts from a peat deposit at Evijärvi, western Finland. Bulletin of the Geological Society of Finland 63, 141-148.

Gadd, P.E., 1751. Försök, Til en Oeconomisk Beskrifning, Ofwer Satacunda Häraders Norra Del/Som innehåller Anmärkningar i Geographie, Antiquiteter, Physique, Historia Naturali, och Oeconomie \& c. Lars Salvii, Stockholm (in Swedish). http://urn.fi/URN:NBN:fi-fd2010-00002533.

Gejvall, N.G., Hjortsjö, C.H., Sahlström, K.E., 1952. Stenålderskvinnan från Luttra. In: Stenberger, M. (Ed.), Arkeologiska Forskningar och Fynd. Svenska Arkeologiska Samfundet, Stockholm, pp. 410-426 (in Swedish).

Goren-Inbar, N., Sharon, G., Melamed, Y., Kislev, M., 2002. Nuts, nut cracking, and pitted stones at Gesher Benot Ya'aqov, Israel. Proceedings of the National Academy of Sciences of the United States of America 99 (4), 2455-2460.

Hämet-Ahti, L., Suominen, J., Ulvinen, T., Uotila, P., 1998. Retkeilykasvio, fourth ed. Finnish Museum of Natural History, Botanical Museum, Helsinki (in Finnish).

Hather, J.G., Mason, S.L.R., 2002. Introduction: some issues in the archaeobotany of hunter-gatherers. In: Mason, S.L.R., Hather, J.G. (Eds.), Hunter-Gatherer 
Archaeobotay. Perspectives from the Northern Temperate Zone. Institute of Archaeology, University College London, London, pp. 1-14.

Hautala, P., 1964. Marjojen ja sienien käyttö Suomen kansanomaisessa ruokataloudessa (Master's thesis). Ethnology, University of Helsinki, Finland (in Finnish).

Hertell, E., 2009. Ekologiat ja maatalouden alku Suomessa. In: Mökkönen, T., Seppälä, S.-L. (Eds.), Arkeologipäivät 2008. Suomen arkeologinen seura, Helsinki, pp. 7-19 (in Finnish).

Hertell, E., Manninen, M., 2006. House pit formation processes: a preliminary assessment of pit 4 at Rävåsen, southern Ostrobothnia, Finland. In: Herva, V. (Ed.), People, Material Culture and Environment in the North, Studia humaniora ouluensia. Faculty of Humanities University of Oulu, pp. 183-197.

Hillman, G., 1981. Reconstructing crop husbandry practices from charred remains of crops. In: Farming Practice in British Prehistory. Edinburgh University Press, Edinburgh, pp. 123-162.

Holmblad, P., 2010. Coastal Communities on the Move House and Polity Interaction in Southern Ostrobothnia 1500 BC-AD 1. In: Archaeology and Environment 26. University of Umeå.

Holst, D., 2010. Hazelnut economy of early Holocene hunter-gatherers: a case study from Mesolithic Duvensee, northern Germany. Journal of Archaeological Science 37, 2871-2880.

Hotanen, J.-P., Nousiainen, H., Mäkipää, R., Reinikainen, A., Tonteri, T., 2013. Metsätyypit - opas kasvupaikkojen luokitteluun, second ed. Metsäkustannus Oy, Porvoo (in Finnish).

Hummel, M., Kiviat, E., 2004. Review of World literature on water chestnut with implications for management in North America. Journal of Aquatic Plant Management 42, 17-28.

Itkonen, T.I., 1921. Lappalaisten ruokatalous. Suomalais-ugrilaisen seuran toimituksia LI. Société Finno-Ougrienne, Helsinki.

Itkonen, T.I., 1984 (1948). Suomen lappalaiset vuoteen 1945, second ed. WSOY, Porvoo (in Finnish).

Jacomet, S., 2013. Archaeobotany. Analyses of plant remains from waterlogged archaeological sites. In: Menotti, F., O'Sullivan, A. (Eds.), The Oxford Handbook of Wetland Archaeology. Oxford University Press, Oxford, pp. 497-514.

Jussila, P., 1996. Site exploitation through macrofossil analysis at different settlement stages of the Pörrinmökki site in Rääkkylä. In: Kirkinen, T. (Ed.), Environmental Studies in Eastern Finland. Reports of the Ancient Lake Saimaa Project, Helsinki Papers in Archaeology 8University of Helsinki, Department of Archaeology, Helsinki, pp. 119-128.

Jussila, T., Kriiska, A., Rostedt, T., 2012. Saarenoja 2 - an Early Mesolithic Site in South-Eastern Finland: preliminary results and interpretations of studies conducted in 2000 and 2008-10. Fennoscandia Archaeologica 29, 3-28.

Karg, S., 2006. The water chestnut (Trapa natans L.) as a food resource during the 4th to 1st millennia BC at Lake Federsee, Bad Buchau (southern Germany). Environmental Archaeology 11, 125-130.

Kirleis, W., Klooß, S., 2014. More than simply fallback food? Social context of plant use in the Northern German Neolithic. In: Chevalier, A., Marinova, E. (Eds.), Plants and People. Choices and Diversity through Time, Early Agricultural Remnants and Technical Heritage (EARTH): 8,000 Years of Resilience and Innovation. Oxbow Books, Oxford \& Philadelphia, pp. 428-466.

Korhola, A., 1990. Suomen metsien kehitysvaiheet. Terra 102, 268-274 (in Finnish).

Korhola, A.A., Tikkanen, M.J., 1997. Evidence for a more recent occurrence of water chestnut (Trapa natans L.) in Finland and its palaeoenvironmental implications. The Holocene 7, 39-44.

Korona, O., 2014. Archaeobotanical finds from the Nadymsky Gorodok medieval settlement in the forest-tundra of Western Siberia, Russia. Vegetation History and Archaeobotany 24, 187-196.

Kubiak-Martens, L., 1999. The plant food component of the diet at the late Mesolithic (Ertebølle) settlement at Tybrind Vig, Denmark. Vegetation History and Archaeobotany 8, 117-127.

Kulttuuriympäristön rekisteriportaali (online Register Portal for Cultural Environment) http://kulttuuriymparisto.nba.fi/netsovellus/rekisteriportaali/portti/ default.aspx (accessed 15.02.15.) (in Finnish).

Kuusipalo, J., 1996. Suomen metsätyypit. Kirjayhtymä Oy, Rauma (in Finnish).

Lahtinen, M., Rowley-Conwy, P., 2013. Early farming in Finland: was there cultivation before the Iron Age (500 BC)? European Journal of Archaeology 16, $660-684$.

Laine, L.J., 2002. Suomalainen Lintuopas, 8th revised edition. Gummerus, Jyväskylä (in Finnish).

Lampinen, R., Lahti, T., Heikkinen, M., 2014. Kasviatlas 2013. Helsingin Yliopisto. Luonnontieteellinen keskusmuseo, Helsinki (in Finnish). http://www.luomus.fi/ kasviatlas (accessed 02.02.15.)

Lempiäinen, T., 1978. The effect of cultivation and fertilizers on Filipendula vulgaris Moench, especially on its tuberous roots. Acta Botanica Fennica 107, 1-22.

Lempiäinen, T., 1997. Kasvillisuuden historiaa Suomen Lapista - Kannattaako makrofossiilitutkimus 65-leveysasteen pohjoispuolella?. In: Schulz, E-L., Carpelan, C. (Eds.), Varhain pohjoisessa: maa. Helsinki Papers in Archaeology 10University of Helsinki Department of Archaeology, Helsinki, pp. 35-48 (in Finnish).

Lempiäinen, T., 2010. Rohto- ja hyötykasveja Päijät-Hämeestä kivikaudelta uudelle ajalle kasvijäännetutkimuksen näkökulmasta. In: Poutiainen, H. (Ed.), Hirviveneestä hullukaaliin Muinaisuskomukset arkeologisen aineiston tulkinnassa. Päijät-Hämeen tutkimusseura ry, Hämeenlinna, pp. 132-145 (in Finnish).

Leskinen, S., 2003. On the dating and function of the comb ceramics from Maarinkunnas. Finskt Museum 102, 5-55.
Lönnrot, E., Sælan, T. (Eds.), 1866. Flora Fennica. Suomen Kasvio. Suomalaisen Kirjallisuuden Seura, Helsinki (in Finnish).

Luoto, J., 1991. Pähkinäpensaan (Corylus avellana) ja tammen (Quercus robur) ravintokäyttö Suomessa esihistoriallisena aikana. Sorbifolia 22 (4), 200-205 (in Finnish).

Maier, U., Harwath, A., 2011. Detecting intra-site patterns with systematic sampling strategies. Archaeobotanical grid sampling of the lakeshore settlement Bad Buchau-Torwiesen II, southwest Germany. Vegetation History and Archaeobotany 20, 349-365.

Mannermaa, K., 2003. Birds in Finnish Prehistory. Fennoscandia Archaeologica 20 54-55.

Manninen, I., 1932. Karjalaisten ruokatalous. In: Härkönen, I. (Ed.), Karjalan Kirja. Werner Söderström Osakeyhtiö, Porvoo Helsinki, pp. 434-446 (in Finnish).

Manninen, I., 1934. Ruoka. Juoma. Nautintoaineet. In: Kannisto, A., Setälä, E.N. Sirelius, U.T., Wichmann, Y. (Eds.), Suomen suku. III osa. Kustannusosakeyhtio Otava, Helsinki, pp. 139-165 (in Finnish).

Manninen, M., Knutsson, K., 2014. Lithic raw material diversification as an adaptive strategy - technology, mobility, and site structure in Late Mesolithic northernmost Europe. Journal of Anthropological Archaeology 33, 84-98.

Mason, S.L., Hather, J.G., Hillman, G.C., 2002. The archaeobotany of European hunter-gatherers: some preliminary investigations. In: Mason, S.L.R. Hather, J.G. (Eds.), Hunter-Gatherer Archaeobotay. Perspectives from the Northern Temperate Zone. Institute of Archaeology, University College London, London, pp. 188-196.

Matiskainen, H., 1989. Studies on the Chronology, Material Culture and Subsistence Economy of the Finnish Mesolithic, 10 000-6000 b.p. Iskos 8 .

Meinander, C.F., 1984. Kivikautemme väestöhistoria. Helsinki. In: Åström, S.-E. (Ed.), Suomen väestön esihistorialliset juuret, Bidrag till kännedom av Finlands natur och folk, H. 131, pp. 21-48 (in Finnish).

Mithen, S., Finlay, N., Carruthers, W., Carter, S., Ashmore, P. 2001. Plant use in the Mesolithic: evidence from Staosnaig, Isle of Colonsay Scotland. Journal of Archaeological Science 28, 223-234.

Mökkönen, T., 2010. Kivikautinen maanviljely Suomessa. Suomen Museo 2009, 5-39 (in Finnish with an English summary).

Mökkönen, T., 2011. Studies on Stone Age Housepits in Fennoscandia (4000-2000 cal BC). Changes in Ground Plan, Site Location, and Degree of Sedentism. Doctoral thesis. University of Helsinki, Finland.

Nunez, M., 1990. On the food resources available to man in Stone Age Finland. Finskt Museum 97, 24-54.

Nunez, M., 1999. Role of food production in Stone Age Finland. In: Fogelberg, P. (Ed.) Pohjan poluilla. Suomalaisten juuret nykytutkimuksen mukaan, Bidrag til kännedom av Finlands natur och folk 153. Suomen Tiedeseura, Helsinki, pp. $133-142$.

Ojala, A.E.K., Alenius, T. Seppä, H., Giesecke, T., 2008. Integrated varve and pollen-based temperature reconstruction from Finland: evidence for Holocene seasonal temperature patterns at high latitudes. The Holocene 18 , 529-538.

Ostlund, L., Bergman, I., Zackrisson, O., 2003. Trees for food - a 3000 year record of subarctic plant use. Antiquity 78, 278-286.

Palmstruch, J.W., 1802-1843. Svensk botanik, Stockholm (in Swedish). http:// runeberg.org/svebotan/.

Pesonen, P., 1999. Suomen esihistoriallinen keramiikka. http://www.helsinki.fi hum/arla/keram/ (accessed 20.01.15.) (in Finnish).

Pesonen, P., Oinonen, M., Carpelan, C., Onkamo, P., 2012. Early Subneolithic ceramic sequences in Eastern Fennoscandia - a Bayesian approach. Radiocarbon 54 (3-4), 661-676.

Pesonen, P., Hertell, E., Simponen, L., Mannermaa, K., Manninen, M.A., Rostedt, T. Taipale, N., Tallavaara, M., 2014. Postglacial pioneer settlement in the Lake Sarvinki area, eastern Finland. In: Riede, F. Tallavaara, M. (Eds.) Lateglacial and Postglacial Pioneers in Northern Europe, British Archaeological Reports, International Series, vol. S2599, pp. 176-192.

Pesonen, P., Sundell, T., 2011. Argeopop-projektin arkeologiset tietokannat. Muinaistutkija 4/2011, pp. 11-18 (in Finnish).

Piezonka, H., 2014. Jäger, Fischer, Töpfer. Wildbeutergruppen mit früher Keramik in Nordosteuropa im 6. und 5. Jahrtausend v. Chr. Archäologie in Eurasien 30 (in German).

Påsse, T., Daniels, J., 2011. Comparison between a new and an old semi-empirica Fennoscandian shore-level model. In: Proceedings of the Seminar "The Sea Level Displacement and Bedrock Uplift." Pori, Finland, 10-11 June 2010, pp. 47-50. Posiva Working Report 2011-07.

Regnell, M., 2011. Plant subsistence and environment at the Mesolithic site Tågerup, southern Sweden: new insights on the "Nut Age". Vegetation History and Archaeobotany 21, 1-16.

Robinson, D.E., 2007. Exploitation of plant resources in the Mesolithic and Neolithic of southern Scandinavia: from gathering to harvesting. In: Colledge, S. Connolly, J. (Eds.), The Origins and Spread of Domestic Plants in Southwest Asia and Europe. Left Coast Press, Walnut Creek, pp. 359-374.

Robinson, D.E., Harild, J.A., 2002. Archaeobotany of an early Ertebølle (Late Mesolithic) site at Halsskov, Zealand, Denmark. In: Mason, S.L.R., Hather, J.G. Eds.), Hunter-Gatherer Archaeobotany. Perspectives from the Northern Temperate Zone. Institute of Archaeology, University College London, London, pp. 84-95.

Seppä, H., Alenius, T., Bradshaw, R.H.W., Giesecke, T., Heikkilä, M., Muukkonen, P. 2009. Invasion of Norway spruce (Picea abies) and the rise of the boreal ecosystem in Fennoscandia. Journal of Ecology 97, 629-640. 
Seppä, H., Schurgers, G., Miller, P.A., Bjune, A.E., Giesecke, T., Kühl, N., Renssen, H., Salonen, J.S., 2015. Trees tracking a warmer climate: the Holocene range shift of hazel (Corylus avellana) in northern Europe. The Holocene 25 (1), 53-63.

Siiriäinen, A., 1981. On the cultural ecology of the Finnish Stone Age. Suomen museo $88,5-40$.

Siiriäinen, A., 1982. Recent studies on the Stone Age economy in Finland. Fennoscandia Antiqua 1, 17-26.

Sirelius, U.T., 1989. (Reprint of an original from 1919) Suomen kansanomaista kulttuuria. In: Esineellisen kansatieteen tuloksia I. Erika-Kirjat, Helsinki (in Finnish).

Sørensen, M., Rankama, T., Kankaanpää, J., Knutsson, K., Knutsson, H., Melvold, S., Valentin Eriksen, B., Glørstad, H., 2013. The first eastern migrations of people and knowledge into Scandinavia: evidence from studies of Mesolithic Technology, 9th-8th millennium BC. Norwegian Archaeological Review 46 (1), 19-56.

Sundell, T., Onkamo, P., 2010. Argeopop: Keramiikasta geenivirtoihin? Muinaistutkija 1/2010, pp. 3-8 (in Finnish).

Sundell, T., Kammonen, J., Halinen, P., Pesonen, P., Onkamo, P., 2014. Archaeology, genetics and a population bottleneck in prehistoric Finland. Antiquity 88 (342), $1132-1147$.

Tallavaara, M., Manninen, M.A., Pesonen, P., Hertell, E., 2014. Radiocarbon dates and postglacial colonisation dynamics in eastern Fennoscandia. In: Riede, F., Tallavaara, M. (Eds.), Lateglacial and Postglacial Pioneers in Northern Europe, British Archaeological Reports, International Series, vol. S2599, pp. 161-175.

Tallavaara, M., Pesonen, P., Oinonen, M., 2010. Prehistoric population history in eastern Fennoscandia. Journal of Archaeological Science 37 (2), 251-260.

Tallavaara, M., Seppä, H., 2011. Did the mid-Holocene environmental changes cause the boom and bust of hunter-gatherer population size in Fennoscandia? The Holocene 22, 215-225.

Talve, I., 1977. Folkligt kosthåll i Finland. En översikt. Etnologiska institutet, Lund (in Swedish).

Tikkanen, M., 1994. Suomen pinnanmuodot. Terra 106, 181-192 (in Finnish).

Til-Landz, E., 1683. Catalogus Plantarum. Aboae (in Latin and Finnish).

Tolar, T., Jacomet, S., Velušček, A., Cufar, K., 2011. Plant economy at a late Neolithic lake dwelling site in Slovenia at the time of the Alpine Iceman. Vegetation History and Archaeobotany 20, 207-222.
Torvinen, M., 2000. Säräisniemi 1-ware. Fennoscandia archaeologica 6, 3-35.

Turner, N., Łuczaj, Ł., Migliorini, P., Pieroni, A., Dreon, A., Sacchetti, L., Paoletti, M. 2011. Edible and tended wild plants, traditional ecological knowledge and agroecology. Critical Reviews in Plant Sciences 30, 198-225.

Valste, J., Albrecht, A., Halinen, A., Piirainen, M., Turunen, S. (Eds.), 2006. Suomen luontotieto. WS Bookwell Oy, Porvoo (in Finnish).

Van der Veen, M., 2007. Formation processes of desiccated and carbonized plant remains - the identification of routine practice. Journal of Archaeological Science 34, 968-990.

Vanhanen, S., Koivisto, S., 2015. Pre-Roman Iron Age settlement continuity and cereal cultivation in coastal Finland as shown by multiproxy evidence at Bäljars 2 site in SW Finland. Journal of Archaeological Science: Reports 1, 38-52.

Viklund, K., 2011. The crowberry connection: environmental archaeology and cultural categorization, examples from Sami contexts. In: Olofsson, A. (Ed.), Archaeology of Indigenous Peoples in the North. Proceedings from a Workshop Held in Vuollerim 6000 år, 3-4 December 2005. Archaeology and Environment 27Department of Historical, Philosophical and Religious Studies, University of Umeå, pp. 183-196.

Vuorela, I., 1999. The beginnings of agricultural land use in Finland: an assessment based on palynological data. In: Miller, U., Hackens, T., Lang, V., Raukas, A. Hicks, S. (Eds.), Environmental and Cultural History of the Eastern Baltic Region. (PACT 57). Conseil de l'Europe, Rixensart, pp. 339-351.

Vuorela, I., Aalto, M., 1982. Palaeobotanical investigations at a Neolithic dwelling site in southern Finland, with special reference to Trapa natans. Annales Botanici Fennici 19, 81-92.

Vuorela, I., Lempiäinen, T., 1988. Archaeobotany of the site of the oldest cereal grain find in Finland. Annales Botanici Fennici 25, 33-45.

Vuorela, T., 1975. Suomalainen kansankulttuuri. Werner Söderström Osakeyhtiö, Porvoo (in Finnish).

Wallenius, J.F., 1782. Om finska allmogens nödbröd. Thesis. University of Turku (in Swedish)http://urn.fi/urn:nbn:fi:fv-12543.

Warren, G., Davis, S., McClatchie, M., Sands, R., 2013. The potential role of humans in structuring the wooded landscapes of Mesolithic Ireland: a review of data and discussion of approaches. Vegetation History and Archaeobotany 23, 629-646.

Zvelebil, M., 1994. Plant use in the Mesolithic and its role in the transition to farming. Proceedings of the Prehistoric Society 60, 35-74. 